\title{
Impact of a Nursing Educational Program on the Expected Post Operative Outcomes of Patients Undergoing Brain Surgeries
}

\author{
Mona Abd El-Maksoud Mohamed, Assistant Lecturer \\ Medical Surgical Nursing, Faculty of Nursing, Alexandria University \\ Haneya Mohammed El-Banna, Professor \\ Medical Surgical Nursing, Faculty of Nursing, Alexandria University \\ Kawther Gaber Tolba, Professor \\ Medical Surgical Nursing, Faculty of Nursing, Alexandria University \\ Osama Saad Abdelaziz, Professor \\ Neurosurgery, Faculty of Medicine, Alexandria University
}

\begin{abstract}
One of the most critical surgeries performed on the human body is brain surgery. Objective: Determine the impact of a nursing educational program on the expected post operative outcomes of patients undergoing brain surgeries. Setting: The study was conducted in the Neurosurgery Inpatient and Outpatient Clinics including Oncology Clinics of Alexandria Main University Hospital, Egypt. Subjects: A convenience sample of 70 adult male and female patients undergoing brain surgery was included in the study and all nurses providing direct care for patients undergoing brain surgeries, their number was a total of 24 nurses. Tools: Five Tools were used for data collection; Tool I: Brain surgery patients' assessment sheet, Tool II: Postoperative brain surgery patients' expected outcomes, Tool III: Nurses knowledge assessment questionnaire, Tool IV: Nurses' performance observation checklist for patients undergoing brain surgeries, Tool V: The nursing educational program for patients undergoing brain surgeries. Results: The study subjects had positive outcomes after implementation of the nursing educational program, more than half of the studied patients achieved satisfaction toward provided nursing care, the knowledge and the performance began to be satisfactory by all nurses caring for the study subjects after application of the nursing educational program. Conclusion: The study concluded that the majority of patients had positive outcomes after the application of the nursing educational program, there were a statistical significant differences between nurses' knowledge and skills before and after application of the nursing educational program. Recommendations: The developed educational program should be given to all patients undergoing brain surgery, and pre-service training program should be provided to the newly appointed nurses
\end{abstract}

Keywords: Nursing educational program; Expected post operative outcomes; Brain surgeries.

\section{Introduction}

Brain surgery is a critical and complicated process. The type of brain surgery done depends highly on the condition being treated. There is a wide range of neurosurgical techniques that has been developed (burr holes, craniotomy and craniectomy) to treat patients with brain $\operatorname{disorders}^{(1)}$.

The postoperative period is the weakest and the most vulnerable phase of a patient's life. The neurosurgical brain procedures are relatively frequent in the daily practice and a wide range of neurosurgical techniques has been developed (burr holes, craniotomy and craniectomy) to treat patients with brain disorders $^{(2)}$.

Educational programs for brain surgeries are considered an important steptoward assuring quality of nursing care. Its focus is to provide a framework within which the multiple activities of nursing care are performed and the needs are to be determined. Avery commonly used framework for organizing an educational 
program is the structure, process and outcome attributes in evaluating quality of care. It provide guidelines used to determine what a nurse should or should not do ${ }^{(3)}$.

An informed and educated patient can actively participate in his or her own treatment, improve outcomes, help identify errors before they occur, and reduce his or her length of stay in the hospital ${ }^{(3)}$.

Complications after brain surgery may include intracranial bleeding, cerebral edema, further neurological impairment, behavioral changes, electrolyte imbalance, infection, seizures, venous thrombosis or hydrocephalus. Hemorrhage at the operative site can occur within hours after surgery. Bleeding may occur in the subdural or subarachnoid space or within the ventricles or at the bed of the lesion ${ }^{(4)}$.

Postoperative care after brain surgery might not end soon in some cases; it could last for months or even years ${ }^{(5)}$. The desired positive outcomes of brain surgery patients include absence or decreased post operative complications, good neurological status, the ability of the care givers to deal with post operative seizures, stability of vital signs, stability of laboratory investigations, reduction of anxiety level, improvement in patients' satisfaction and absence of patient problems $^{(6)}$.

\section{Aim of the Study}

The present study aim is to determine the impact of a nursing educational program on the expected post operative outcomes of patients undergoing brain surgeries.

\section{Research Hypothesis}

Nurses caring patients undergoing brain surgeries who will receive the nursing educational program demonstrate better knowledge after implementation of the educational program, than before, also nurses caring for patients undergoing brain surgeries who will receive the nursing educational program exhibit better performance after implementation of the educational program, than before and patients undergoing brain surgeries and cared for by nurses, who will receive the nursing educational program exhibit better outcomes than those who receive routine hospital nursing interventions.

\section{Materials and Method}

\section{Materials}

Design: A quasi experimental research design was utilized to achieve the aim of this study.

Setting: The study was conducted in the Neurosurgery inpatient and outpatient clinics including oncology clinics of Alexandria Main University Hospital, Egypt.

Subjects: Subjects of the study comprised two groups, seventy adult male and female patients undergoing brain surgery aged from 21 to less than 65 years, able to communicate verbally, alert and able to follow instructions, free of associating illnesses, admitted at least one day prior to surgery and willing to participate. Another group of nurses providing direct care for patients undergoing brain surgeries throughout the period of data collection, were recruited. Their number was a total of 24 nurses.

Tools: Five tools were used to collect the necessary data:

\section{Tool I: Brain Surgery Patients' Health Status Assessment}

This tool was developed based a thorough review of related literature to assess the brain surgery patients' health status. It consists of five parts as follows: Part 1: Socio-demographic characteristics of patients. Part II: Patients' clinical data. Part III. Neurological assessment. Part IV. Laboratory investigations. Part V. Brain surgeries patients' headache assessment.

Tool II: Postoperative Brain Surgery Patients' Expected Outcomes Assessment 
This tool contained two parts, Part I: includes an assessment of the postoperative brain surgery patients' expected outcomes. Every achieved expected outcome was scored as one. The total score for each patient was calculated then converted to percentage as follows: "Negative outcomes" $50-64 \%$ "Moderate level of positive outcomes" 65-84\% and "positive outcomes "85-100\%.Part II: Postoperative brain surgery patients' satisfaction toward provided nursing interventions. This part was developed by Chunlaka (2011) It is composed of 20 items in the form of statements grouped into 5 dimensions namely assurance, empathy, reliability, responsiveness, and tangibility. Each dimension contains 4 statements. The total scores for every patient was calculated then converted to a percentage as follows: "Lowest level of satisfaction" 33-55\%, "Moderate level of satisfaction "55-77\%, and "highest level of satisfaction" 77$100 \% .{ }^{(7)}$.

\section{Tool III: Nurses Knowledge Assessment \\ Questionnaire}

This tool includes included a group of open and closed ended questions about the meaning of brain surgery, pre and postoperative precautions, perioperative care and warning signs/complications to report the doctor, how to deal with seizure(s), knowledge related to prescribed medication, dietary measures as well as knowledge related to infection control measures. Each right answer was given one score. Those who obtained less than $(60 \%)$ were considered having "unsatisfactory" level of knowledge. Above (60\%) was considered having "satisfactory" level of knowledge.

\section{Tool IV: Nurses' Performance Observation Checklist for Patients Undergoing Brain Surgeries}

This tool is composed of a checklist of nurses activities provided for brain surgery assessment as care of wound site, care of wound drain, perioperative care, pain management measures, how to deal with post operative seizures, infection control measures, providing health teaching for patient about life style modifications. The observations were checked by the researcher until, completion of all parts of the nurses' performance Each practice involving sub nursing competencies were checked and scored as follows" Done adequately" was scored as (2), "done in adequately " was scored as (1), or" not done" was scored as $(0)$. The level of nurses practices performances were categorized as follows: Good practice: $75-100 \%$, satisfactory practice: $50<75 \%$, poor practice: $<50$.

Tool V: The Nursing Educational Program for Patients Undergoing Brain Surgeries

Program contents covered the following areas: brief anatomy of the brain structure, definition and indications for brain surgery, various diagnostic procedures and patient preparation, benefits of surgical management and types of brain surgeries, neurological assessment systemic and neurosurgical postoperative complications after brain surgery, medical therapy after brain surgery and the nursing role, pursed lip breathing exercise, infection control measures and routine follow up and when it is necessary to seek medical.

\section{Method}

- The study protocol was approved by the Post graduate and Ethical Research committees, faculty of nursing and Alex University.

- An official letter from Alexandria University, Faculty of Nursing was submitted to the general directors of Main University Hospital and the head of the Neurosurgery Department.

- Reliability testing for the study tools was estimated using the Cronbach's Alpha test of the study tools. Results indicated that the tool I had Cronbach's Alpha coefficient of: 0.85. Tool II had Cronbach's Alpha coefficient of: 0.73.Tool III had 
Cronbach's Alpha coefficient of: 0.77

Tool IIII had Cronbach's Alpha coefficient of: 0.891 .

- A pilot study was conducted on 7 adult patients and four nurses.

- The study was carried out on four phase:

\section{- Assessment phase:}

The initial assessment was carried out $24 \mathrm{hrs}$ preoperatively using the tools I and II for both group subjects patients. For nurses' assessment was carried out to assess their knowledge and performances regarding brain surgery patients' routine care, using tools III and IV, before application of the nursing educational. The subsequent assessment for the patients was done on discharge, one and three months postoperatively in order to evaluate the impact of the nursing educational program on post operative outcomes. Nurses were reassessed for knowledge using tool III and watched for their performances and clinical skills regarding brain surgery patients' care, using tools IV on the first day after discharge from ICU, and on discharge, as the third observation.

\section{- Planning phase:}

The nursing educational program contents were developed based on a review of related literature as well the assessment phase findings. Audiovisual materials (in the form of the program booklet was provided for the enrolled nurses

\section{- Implementation phase:}

The developed educational program was initially introduced individually for each nurse and the teaching sessions to cover the program content for both theory and practice were scheduled. These nurses were divided, thereafter into small groups, 4 to 5 nurses, each.

\section{- Evaluation phase:}

This phase was carried out using study tools one and three months post discharge for patient.

'Nurses were evaluated using tools III and IV.

\section{Ethical considerations:}

Written consents of the enrolled patients and nurses to participate in the study were obtained, privacy was maintained and confidentiality was secured. Participant's right to be withdrawn at any time of the study was considered and respected.

\section{Statistical Analysis}

Data were analyzed using "SPSS" software version 20. Cronbach's alpha reliability test, was used to measure the reliability of the developed tools. Comparisons between both groups were carried out using Mann-Whitney U test for the quantitative variable while Chi-Square $(\chi 2)$ and Monte Carlo testes for qualitative variables. T-test was used to test association between two quantitative variables. Fisher's exact (FET) test was used for comparisons between the distributions of two qualitative variables.

\section{Results}

Table (1) shows that more than half of study and control groups $(57.1 \%, 54.3 \%$, respectively) were "males". Less than half of study and control subjects (42.9\%) were aged between "40-50"years old. The majority the study and control group subjects i.e. $85.7 \%, 88.6$, respectively were "married".

Table (2) shows that the majority of both study and control group subjects $(77.1 \%$, $68.6 \%$, respectively) had brain tumors, all of the study and control group subjects $(100 \%)$ were on "anticonvulsants, analgesics, antibiotics and steroids". Also the majority of the study and control subjects (82.9\%, 
$85.7 \%$, respectively) had craniotomy. Less than half of the two group subjects $(34.28 \%$, $28.57 \%$ of the study and their controls, respectively were "smoker".

Table (3) shows that all of the studied subjects $(100 \%)$ reported that they initiated necessary "lifestyle changes" and the majority i.e. $94.3 \%$, 97.1, respectively) reported that the "headache" was relieved The same table shows that more than half of the study subjects $(57.1 \%)$ demonstrated positive outcomes compared to their controls, none of them demonstrated positive outcomes and more than half of the control subjects $(74.3 \%)$ demonstrated negative outcomes. Statistical significant differences were revealed between the two group subjects regarding "postoperative expected outcomes" where $\mathrm{p}(<0.001 *)$.

Table (4) shows that $(100.0 \%)$ of the studied patients demonstrate the lowest level of satisfaction before the application of the nursing educational program compared with three months later, where $(82.9 \%)$ of the studied subjects indicated "highest level of satisfaction". Statistical significant differences between the study and control subjects were elicited where $(\mathrm{P}=<0.001 *)$.

Table (5) displays that more than half of nurses caring for the study subjects i.e. $66.7 \%$ were in the age group of "30>45" years old. All nurses caring for the study and control subjects $(100 \%)$. were currently married and their experiences more than six years .The majority of nurses caring for the study subjects (91.6\%) were diploma graduates. Almost all of the nurses caring for the study and control subjects $(91.7 \%)$ had no" previous attendance of training programs" related to brain surgery.

Table (6) shows that the overall knowledge of the nurses caring for the study subjects preoperatively was "unsatisfactory" i.e. $91.7 \%$ which began to improve to be "satisfactory" by $100 \%$ after application of the nursing educational program, compared with their controls $(83.3 \%)$ who had "unsatisfactory level of knowledge" with routine nursing care .Statistical significant differences between the two groups where (p2 and p3=0.001*).

Table (7) shows that more than the half of the nurses caring for the study subjects $66.7 \%$ had "poor" level of performances pre operatively, which improved to be "good" by $(75 \%)$ after application of the nursing educational program, while caring for the controls were demonstrating" poor" level with routine nursing care.

\section{Discussion}

Ongoing educational programs are necessary for consistent promotion of selfmanagement practices, controlling symptoms and prevention of complications. The findings of the current study revealed that more than half of study and control patients were males from 40-50 years old and the majority of them were married. These results agree with a study by BinMadhi, (2012) entitled as "Brain tumors excision guided by neuronavigation: Practical application and results" which revealed that brain surgery is more frequently undergone in males than females with a mean age of 47 years old ${ }^{(8)}$.

It was observed that the highest percentage of both study and control subjects were illiterate. Dankner (2009) reported that that the highest percentage of his study subjects who had neurological diseases were illiterate or had primary education $^{(9)}$, the results revealed that the majority of both study and control subjects had been diagnosed with brain tumors. In this regard Amit (2019) reported that the indications for brain surgery include brain tumors, bleeding (hemorrhage) or blood clots (hematomas) from injuries ${ }^{(10)}$.

The results revealed that all of the study and control subjects $(100 \%)$ were on anticonvulsants, analgesics, antibiotics and steroids. White et al. (2013) recommended that patients after brain surgery require a variety of medical treatment ${ }^{(11)}$. The findings of the current study revealed that more than half of study and control subjects had 
undergone craniotomy. Van de Beek et al (2010) stated that craniotomy is widely used in neuroscience for accessing brain tissue that must be removed ${ }^{(12)}$. Also many of both study and control subjects were found to have history of smoking In this context, Mandelzweig et al. (2009) reported that smoking is a risk factor for brain tumors especially gliomas $^{(13)}$.

The current study findings revealed that around one quarter of the study subjects had headache and visual disturbances. Urden et al., 2010 and Krucik, 2012 indicated that the more common clinical manifestations of brain tumors, brain abscess, subdural hematoma and cystic lesion within the intracranial cavity are headache, drowsiness, visual disturbances, changes of conscious level, seizures and motor deficit ${ }^{(14,15)}$. The study findings revealed that all the study and control subjects were conscious. No doubt, these post brain surgery patients were clinically improved due to the relieved pressure of the tumor, haematoma, abscess or cyst $^{(16)}$.

The results of the present study revealed that the majority of both of the study and control subjects were normotensive and had no post operative vomiting nor nausea or myocardial infarction. interestingly Buttaro (2013) demonstrated that unmanaged stress is linked hypertension and heart diseases after brain surgery ${ }^{(17)}$.

The findings of the present study revealed that the study and control subjects suffered from headache before surgery which improved throughout the follow up periods. Lindsay et al. (2004) reported that headache is an associating symptom of increased ICP due to compression of pain sensitive structures within the intracranial compartment and the most important factor that should be considered after brain surgery is avoiding of the straining factors that lead to increase of the $\mathrm{ICP}^{(18)}$.

Few of the current study group patients were found having seizures in the preoperative phase. This patient number (4), was considerably lowered in the postoperative assessment following the nursing program instructions, could be probably be a factor for the formational study findings According to Westcarth (2007) seizures are common brain tumor symptoms, occurring in $(60 \%)$ of all brain tumor patients and they may be the first indication of brain tumor surgery and also the most common complications after intracranial surgery, so it should be avoided by follow the postoperative instructions that given from the nurses and the surgeon ${ }^{(19)}$.

The findings of the present study revealed that all studied patients $(100 \%)$ initiated necessary lifestyle changes and most of them reported that headache was relieved and demonstrated stabilized vital signs as well as within normal laboratory studies. in this context, Spears (2005) reported that patient' outcomes were improved after application of educational programs for the nurses staff ${ }^{(20)}$.

The present study results displayed that the highest percent of the studied nurses were Diploma of the Secondary School of Nursing graduates. These results were supported by Elreefay (2012) had similar findings ${ }^{(21)}$. Also the majority of nurses caring for both study and control subjects had not been enrolled in previous training programs related to brain surgery. Annette (2007) reported that in service training in nursing is considered as a necessary component to help professional nurse keep up to date on the most recent developments in nursing and to be able to manage the demands of nursing practice ${ }^{(22)}$.

The current study revealed that, the most of studied nurses had unsatisfactory level of knowledge. Also there was a notable statistical significant difference between nurses' knowledge before and after receiving the nursing educational program. Aiken et al (2012) and Shrestha (2013) noted that negative patient outcomes often were due to lack of training and direction from one that is responsible of nursing services. ${ }^{(23,24)}$. 
No Arabic source for updating and continuing nurses education were available. Also this may be attributed to lack of continuous education and absence of preservice and training program.

The present results pointed out that, there were statistical positive significant differences in nurses' performance before and after receiving the nursing educational program. Ookalkar (2009) claimed that the in service training has a beneficial effect in improving the nurse's knowledge and skills. Those educational programs should be organized according to the needs of nurses with continuing evaluation ${ }^{(25)}$.

Educational programs contributed to positive outcomes since nursing interventions for patients undergoing brain surgery can improve the health outcomes and reduce the risk of complications. It is important for nurses to meet the care needs of patients through education, support, supervision, and reinforcement.

\section{Conclusion}

Based on the findings of the present study, it can be concluded that the majority of patients had positive outcomes after the application of the nursing educational program.

\section{Recommendations}

\section{- Recommendations for patients:}

- The developed booklet should be available and distributed to all patients undergoing brain surgery in the study setting, and outpatient clinics.

- The developed educational program should be given to all patients undergoing brain surgery.

\section{- Recommendations for nurses}

- Pre-service training program should be provided to the newly appointed nurses before assuming independent responsibilities for brain surgery's patients' care.

- Developed competencies handout about care for patient undergoing brain surgery should be available for all staff nurses that caring these patients.

- Reasonable nurse/patient ratio should be properly distributed in all shifts for maintaining good quality nursing care.

- Recommendations for the administrators:

- Administrative staff should plan for periodic patient teaching programs about brain disorders and its management as one of hospital policies, and procedures

- Preservice and inservice programs, for newly employed nurses about care needed for brain surgery patients, are needed.

\section{- Further recommended researches}

- Exploring the impact of educational programs for patients undergoing brain surgery on their quality of life

- Exploring the effect of implementing developed nursing rehabilitation programs for brain surgery's patients on their physical and psychological status. 
Table (1): Frequency distribution of the study and control subjects according to their sociodemographic characteristics

\begin{tabular}{|c|c|c|c|c|c|c|}
\hline \multirow{2}{*}{$\begin{array}{l}\text { Socio-demographic } \\
\text { characteristics of patients }\end{array}$} & \multicolumn{2}{|c|}{$\begin{array}{c}\text { Study } \\
(\mathbf{n}=\mathbf{3 5})\end{array}$} & \multicolumn{2}{|c|}{$\begin{array}{l}\text { Control } \\
(\mathbf{n}=\mathbf{3 5})\end{array}$} & \multirow{2}{*}{$\begin{array}{l}\text { Test of } \\
\text { Sig. }\end{array}$} & \multirow[t]{2}{*}{$\mathbf{P}$} \\
\hline & $\begin{array}{l}\text { No. } \\
\end{array}$ & $\%$ & No. & $\%$ & & \\
\hline \begin{tabular}{|l} 
Sex \\
Male \\
Female
\end{tabular} & $\begin{array}{l}20 \\
15\end{array}$ & $\begin{array}{l}57.1 \\
42.9\end{array}$ & $\begin{array}{l}19 \\
16\end{array}$ & $\begin{array}{l}54.3 \\
45.7\end{array}$ & $\begin{array}{c}\chi^{2}= \\
0.058\end{array}$ & 0.810 \\
\hline \begin{tabular}{|l|} 
Age \\
$20<30$ years \\
$30<40$ years \\
$40<50$ years \\
$50 \geq 60$ years \\
\end{tabular} & $\begin{array}{c}5 \\
6 \\
15 \\
9 \\
\end{array}$ & $\begin{array}{l}14.3 \\
17.1 \\
42.9 \\
25.7\end{array}$ & $\begin{array}{c}4 \\
7 \\
15 \\
9 \\
\end{array}$ & $\begin{array}{l}11.4 \\
20.0 \\
42.9 \\
25.7\end{array}$ & $\begin{array}{c}\chi^{2}= \\
0.302\end{array}$ & $\begin{array}{l}{ }_{\mathrm{p}}^{\mathrm{MC}}= \\
1.000\end{array}$ \\
\hline $\begin{array}{l}\text { Level of education } \\
\text { Illiterate } \\
\text { Reads and writes } \\
\text { Primary\& Preparatory } \\
\text { Secondary } \\
\text { Higher education }\end{array}$ & $\begin{array}{c}21 \\
5 \\
5 \\
2 \\
2 \\
\end{array}$ & $\begin{array}{c}60.0 \\
14.3 \\
14.3 \\
5.7 \\
5.7\end{array}$ & $\begin{array}{c}20 \\
6 \\
2 \\
6 \\
1\end{array}$ & $\begin{array}{c}57.1 \\
17.1 \\
5.7 \\
17.1 \\
2.9\end{array}$ & $\begin{array}{c}\chi^{2}= \\
3.681\end{array}$ & $\begin{array}{l}{ }_{\mathrm{p}}^{\mathrm{MC}}= \\
0.470\end{array}$ \\
\hline \begin{tabular}{|l|} 
Marital status \\
Single \\
Married
\end{tabular} & $\begin{array}{c}5 \\
30\end{array}$ & $\begin{array}{l}14.3 \\
85.7\end{array}$ & $\begin{array}{c}4 \\
31 \\
\end{array}$ & $\begin{array}{l}11.4 \\
88.6\end{array}$ & $\begin{array}{c}\chi^{2}= \\
0.128\end{array}$ & $\begin{array}{l}{ }^{\mathrm{FE}} \mathrm{p}= \\
1.000\end{array}$ \\
\hline \begin{tabular}{|l} 
Occupation \\
Professional work \\
Manual work \\
Housewife \\
Pension \\
\end{tabular} & $\begin{array}{c}4 \\
11 \\
13 \\
7 \\
\end{array}$ & $\begin{array}{l}11.4 \\
31.4 \\
37.1 \\
20.0 \\
\end{array}$ & $\begin{array}{c}5 \\
10 \\
12 \\
8 \\
\end{array}$ & $\begin{array}{l}14.3 \\
28.6 \\
34.3 \\
22.9 \\
\end{array}$ & $\begin{array}{c}\chi^{2}= \\
0.372\end{array}$ & $\begin{array}{l}{ }_{\mathrm{pC}}= \\
1.000\end{array}$ \\
\hline \begin{tabular}{|l} 
Residence area \\
Urban \\
Rural
\end{tabular} & $\begin{array}{l}15 \\
20\end{array}$ & $\begin{array}{l}42.9 \\
57.1\end{array}$ & $\begin{array}{l}13 \\
22 \\
\end{array}$ & $\begin{array}{l}37.1 \\
62.9\end{array}$ & $\begin{array}{c}\chi^{2}= \\
0.238\end{array}$ & 0.626 \\
\hline
\end{tabular}

$\chi^{2}$ : Chi square test $\quad t$ : Student $t$-test

MC: Monte Carlo

FE: Fisher Exact 
Table (2): Frequency distribution of the study and control subjects according to their clinical data

\begin{tabular}{|c|c|c|c|c|c|c|}
\hline \multirow[t]{2}{*}{ Patient's clinical data } & \multicolumn{2}{|c|}{$\begin{array}{c}\text { Study } \\
(\mathbf{n}=35)\end{array}$} & \multicolumn{2}{|c|}{$\begin{array}{l}\text { Control } \\
(\mathbf{n}=35)\end{array}$} & \multirow[t]{2}{*}{$\chi^{2}$} & \multirow[t]{2}{*}{$\mathbf{P}$} \\
\hline & No. & $\%$ & No. & $\%$ & & \\
\hline Diagnosis & & & & & \multirow{6}{*}{$\begin{array}{c}\chi^{2}= \\
0.979\end{array}$} & \multirow{6}{*}{$\begin{array}{r}{ }_{\mathrm{MC}}^{\mathrm{p}}= \\
0.875\end{array}$} \\
\hline Brain tumor & 27 & 77.1 & 24 & 68.6 & & \\
\hline Left parietal cystic lesion & 4 & 11.4 & 6 & 17.1 & & \\
\hline Sub-dural hematoma & 2 & 5.7 & 3 & 8.6 & & \\
\hline Obstructed hydrocephalus & 2 & 5.7 & 2 & 5.7 & & \\
\hline Previous neurological surgery & & & & & & \\
\hline No & 34 & 97.1 & 32 & 91.4 & \multirow{2}{*}{$\begin{array}{c}\chi^{2}= \\
1.061\end{array}$} & \multirow{2}{*}{$\begin{array}{c}{ }^{\mathrm{FE}} \mathrm{p}= \\
0.303\end{array}$} \\
\hline Yes & 1 & 2.9 & 3 & 8.6 & & \\
\hline \begin{tabular}{|l|} 
Family history of brain disease or brain \\
surgery? \\
No \\
Yes
\end{tabular} & $\begin{array}{c}34 \\
1\end{array}$ & $\begin{array}{c}97.1 \\
2.9\end{array}$ & $\begin{array}{c}32 \\
3\end{array}$ & $\begin{array}{c}91.4 \\
8.6\end{array}$ & 1.061 & ${ }^{\mathrm{FE}} \mathrm{p}=0.303$ \\
\hline $\begin{array}{l}\text { Medical treatment after surgery } \\
\text { Anticonvulsants } \\
\text { Analgesics } \\
\text { Antibiotics } \\
\text { steroids }\end{array}$ & $\begin{array}{l}35 \\
35 \\
35 \\
35\end{array}$ & $\begin{array}{l}100.0 \\
100.0 \\
100.0 \\
100.0\end{array}$ & $\begin{array}{l}35 \\
35 \\
35 \\
35\end{array}$ & $\begin{array}{l}100.0 \\
100.0 \\
100.0 \\
100.0\end{array}$ & $\begin{array}{l}- \\
- \\
-\end{array}$ & $\begin{array}{l}- \\
- \\
-\end{array}$ \\
\hline $\begin{array}{l}\text { Type of surgery } \\
\text { Craniotomy } \\
\text { Craniectomy } \\
\text { Borehole } \\
\end{array}$ & $\begin{array}{c}29 \\
2 \\
4\end{array}$ & $\begin{array}{c}82.9 \\
5.7 \\
11.4\end{array}$ & $\begin{array}{c}30 \\
2 \\
3\end{array}$ & $\begin{array}{c}85.7 \\
5.7 \\
8.6\end{array}$ & 0.338 & ${ }^{\mathrm{MC}} \mathrm{p}=1.000$ \\
\hline $\begin{array}{l}\text { Patient smoking habits } \\
\text { smoker } \\
\text { not smoker }\end{array}$ & $\begin{array}{l}12 \\
23 \\
\end{array}$ & $\begin{array}{l}34.28 \\
65.72 \\
\end{array}$ & $\begin{array}{l}10 \\
25 \\
\end{array}$ & $\begin{array}{l}28.57 \\
71.43 \\
\end{array}$ & 0.057 & 0.811 \\
\hline $\begin{array}{l}\text { Previous neurological problems } \\
\text { Headache } \\
\text { Change in consciousness } \\
\text { Visual disturbances } \\
\text { Dizziness } \\
\text { Seizures }\end{array}$ & $\begin{array}{c}10 \\
1 \\
10 \\
5 \\
3\end{array}$ & $\begin{array}{c}28.6 \\
2.9 \\
28.6 \\
14.3 \\
8.6\end{array}$ & $\begin{array}{c}18 \\
2 \\
3 \\
5 \\
5\end{array}$ & $\begin{array}{c}51.4 \\
5.7 \\
8.6 \\
14.3 \\
14.3\end{array}$ & $\begin{array}{c}3.810 \\
0.348 \\
4.629^{*} \\
0.00 \\
0.565\end{array}$ & $\begin{array}{c}0.051 \\
{ }^{\mathrm{FE}} \mathrm{p}=1.000 \\
0.031^{*} \\
1.000 \\
{ }_{\mathrm{FE}} \mathrm{p}=0.710\end{array}$ \\
\hline \begin{tabular}{|l} 
Radiological examination \\
CT \\
MRI
\end{tabular} & $\begin{array}{c}6 \\
29 \\
\end{array}$ & $\begin{array}{l}17.1 \\
82.9\end{array}$ & $\begin{array}{c}5 \\
30 \\
\end{array}$ & $\begin{array}{l}14.3 \\
85.7\end{array}$ & 0.108 & 0.743 \\
\hline
\end{tabular}

p: $p$ value for comparing between the two studied groups 
Table (3): Distribution of the study and control subjects according to postoperative patient's expected outcomes

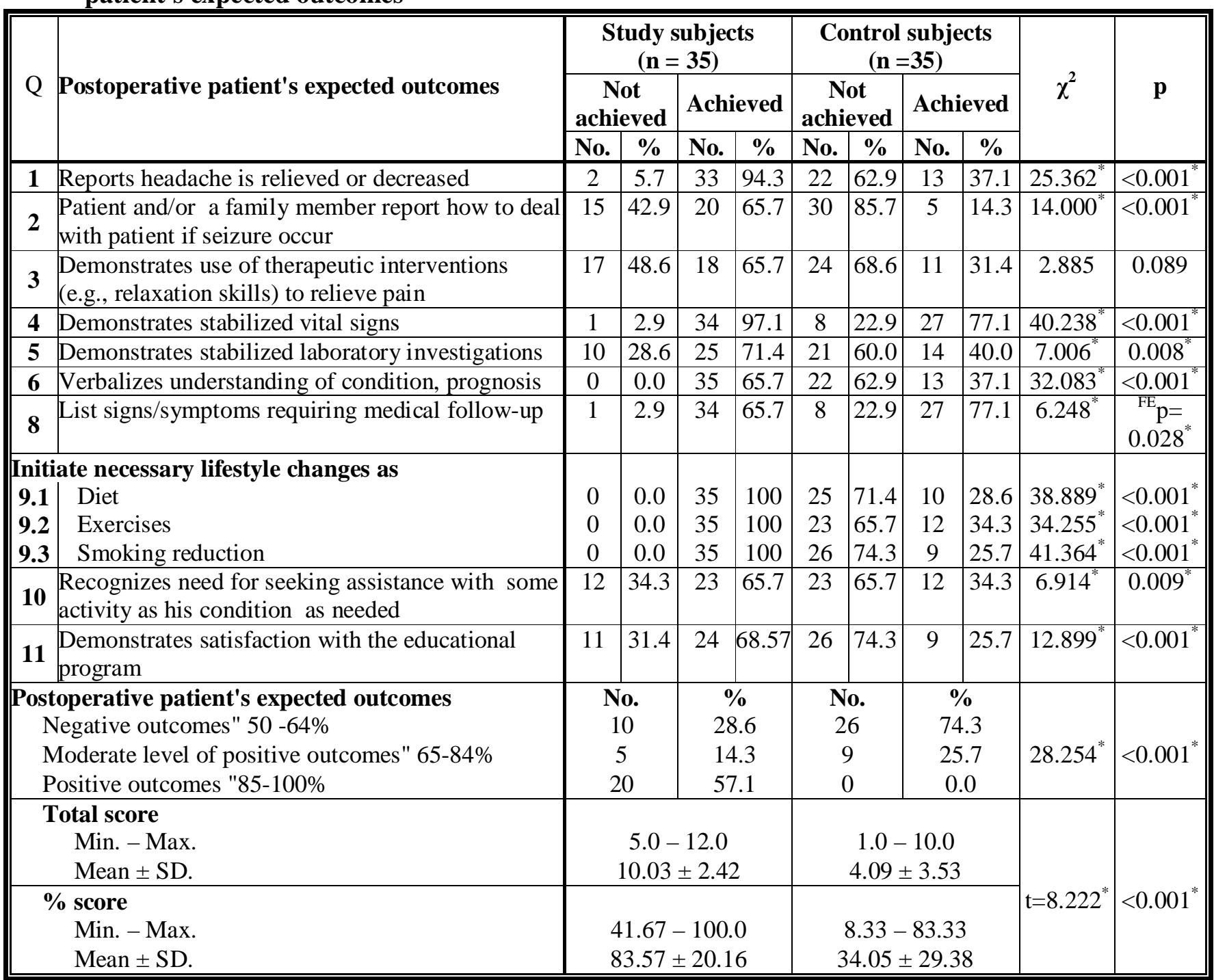

*: Statistically significant at $p \leq 0.05$

Table (4): Study subjects satisfaction before and after implementation of nursing educational program $(n=35)$

\begin{tabular}{|c|c|c|c|c|c|c|c|c|c|c|c|c|c|}
\hline \multirow{3}{*}{$\begin{array}{l}\text { Study subjects } \\
\text { items }\end{array}$} & \multicolumn{6}{|c|}{$\begin{array}{c}\text { Before implementation of nursing } \\
\text { educational program }\end{array}$} & \multicolumn{6}{|c|}{$\begin{array}{c}\text { After implementation of nursing } \\
\text { educational program }\end{array}$} & \multirow{3}{*}{${ }^{{ }^{\mathrm{MH}}} \mathbf{p}$} \\
\hline & \multicolumn{2}{|c|}{\begin{tabular}{|c|} 
Lowest \\
level of \\
satisfaction
\end{tabular}} & \multicolumn{2}{|c|}{$\begin{array}{c}\text { Moderate } \\
\text { level of } \\
\text { satisfaction }\end{array}$} & \multicolumn{2}{|c|}{$\begin{array}{c}\text { Highest } \\
\text { level of } \\
\text { satisfaction }\end{array}$} & \multicolumn{2}{|c|}{$\begin{array}{c}\begin{array}{c}\text { Lowest } \\
\text { level of } \\
\text { satisfaction }\end{array} \\
\end{array}$} & \multicolumn{2}{|c|}{$\begin{array}{c}\text { Moderate } \\
\text { level of } \\
\text { satisfaction }\end{array}$} & \multicolumn{2}{|c|}{$\begin{array}{c}\text { Highest } \\
\text { level of } \\
\text { satisfaction }\end{array}$} & \\
\hline & \begin{tabular}{|l} 
No. \\
\end{tabular} & $\%$ & No. & $\%$ & No. & $\%$ & No. & $\%$ & \begin{tabular}{|l} 
No. \\
\end{tabular} & $\%$ & No. & $\%$ & \\
\hline Assurance & 33 & 94.3 & 2 & 5.7 & 0 & 0.0 & 0 & 0.0 & 10 & 28.6 & 25 & 71.4 & $<0.001$ \\
\hline Empathy & 29 & 82.9 & 5 & 14.3 & 1 & 2.9 & 0 & 0.0 & 15 & 42.9 & 20 & 57.1 & $<0.001^{*}$ \\
\hline Reliability & 28 & 80.0 & 7 & 20.0 & 0 & 0.0 & 0 & 0.0 & 10 & 28.6 & 25 & 71.4 & $<0.001^{*}$ \\
\hline Responsiveness & 30 & 85.7 & 5 & 14.3 & 0 & 0.0 & 0 & 0.0 & 10 & 28.6 & 25 & 71.4 & $<0.001^{*}$ \\
\hline Tangibility & 28 & 80.0 & 6 & 17.1 & 1 & 2.9 & 0 & 0.0 & 8 & 22.9 & 27 & 77.1 & $<0.001^{*}$ \\
\hline $\begin{array}{l}\text { Overall } \\
\text { satisfaction }\end{array}$ & 35 & 100.0 & 0 & 0.0 & 0 & 0.0 & 0 & 0.0 & 6 & 17.1 & 29 & 82.9 & $<0.001^{*}$ \\
\hline
\end{tabular}


Table (5): Socio-demographic data of nurses caring for the study and control subjects

\begin{tabular}{|c|c|c|c|c|c|c|}
\hline \multirow[t]{2}{*}{$\begin{array}{l}\text { Nurse's Socio demographic } \\
\text { data }\end{array}$} & \multicolumn{2}{|c|}{$\begin{array}{l}\text { Nurses caring } \\
\text { for the study } \\
\text { subjects } \\
(\mathrm{n}=12)\end{array}$} & \multicolumn{2}{|c|}{$\begin{array}{l}\text { Nurses caring } \\
\text { for the control } \\
\text { subjects } \\
(\mathrm{n}=12) \\
\end{array}$} & \multirow[t]{2}{*}{$\chi^{2}$} & \multirow[t]{2}{*}{$\mathbf{P}$} \\
\hline & No. & $\%$ & No. & $\%$ & & \\
\hline $\begin{array}{l}\text { Age (years) } \\
20>30 \\
30>45 \\
>45\end{array}$ & $\begin{array}{l}3 \\
8 \\
1 \\
\end{array}$ & $\begin{array}{c}25.0 \\
66.7 \\
8.3\end{array}$ & $\begin{array}{c}0 \\
12 \\
0\end{array}$ & $\begin{array}{c}0.0 \\
100.0 \\
0.0\end{array}$ & $7.738^{*}$ & $\begin{array}{l}{ }_{\mathrm{MC}}^{\mathrm{p}}= \\
0.014^{*}\end{array}$ \\
\hline $\begin{array}{l}\text { Educational qualification } \\
\text { Bachelor } \\
\text { Technical } \\
\text { Diploma } \\
\text { Other } \\
\end{array}$ & $\begin{array}{c}0 \\
1 \\
11 \\
0\end{array}$ & $\begin{array}{c}0.0 \\
8.4 \\
91.6 \\
0.0 \\
\end{array}$ & $\begin{array}{c}0 \\
0 \\
12 \\
0\end{array}$ & $\begin{array}{c}0.0 \\
0.0 \\
100.0 \\
0.0\end{array}$ & 2.274 & $\begin{array}{l}\mathrm{FE}_{\mathrm{p}}= \\
0.317\end{array}$ \\
\hline $\begin{array}{l}\text { Years of experience (years) } \\
>1 \\
1>3 \\
3>6 \\
>-6 \\
\end{array}$ & $\begin{array}{c}0 \\
0 \\
0 \\
12 \\
\end{array}$ & $\begin{array}{c}0.0 \\
0.0 \\
0.0 \\
100.0\end{array}$ & $\begin{array}{c}0 \\
0 \\
0 \\
12 \\
\end{array}$ & $\begin{array}{c}0.0 \\
0.0 \\
0.0 \\
100.0\end{array}$ & - & - \\
\hline $\begin{array}{l}\text { Social status } \\
\text { Single } \\
\text { Married } \\
\text { Divorce } \\
\text { Widow } \\
\end{array}$ & $\begin{array}{c}0 \\
12 \\
0 \\
0\end{array}$ & $\begin{array}{c}0.0 \\
100.0 \\
0.0 \\
0.0 \\
\end{array}$ & $\begin{array}{c}0 \\
12 \\
0 \\
0 \\
\end{array}$ & $\begin{array}{c}0.0 \\
100.0 \\
0.0 \\
0.0\end{array}$ & - & - \\
\hline $\begin{array}{l}\text { Previous attendance of a } \\
\text { training program } \\
\text { No } \\
\text { Yes } \\
\end{array}$ & $\begin{array}{c}11 \\
1 \\
\end{array}$ & $\begin{array}{c}91.7 \\
8.3 \\
\end{array}$ & $\begin{array}{c}11 \\
1 \\
\end{array}$ & $\begin{array}{c}91.7 \\
8.3 \\
\end{array}$ & 1.043 & $\begin{array}{l}\mathrm{FE}_{\mathrm{p}}= \\
1.000\end{array}$ \\
\hline
\end{tabular}

$\chi^{2}$ : Chi square test

MC: Monte Carlo

FE: Fisher Exact

$p$ : $p$ value for comparing between study and control group

*: Statistically significant at $p \leq 0.05$. 
Educational Program, Brain Surgeries, Post Operative Outcomes

Table (6): Knowledge of nurses caring for the study and control subjects, pre-operatively, one month and three months after

\begin{tabular}{|c|c|c|c|c|c|c|c|c|c|c|c|c|c|c|c|c|c|c|c|c|c|c|c|c|c|c|c|}
\hline \multirow{4}{*}{ Knowledge items } & \multicolumn{12}{|c|}{ Nurses caring for the study subjects $(\mathrm{n}=12)$} & \multicolumn{12}{|c|}{ Nurses caring for the control y subjects $(\mathrm{n}=12)$} & \multirow{4}{*}{$2\left(\mathrm{~F}^{(\mathrm{F}} \mathrm{p}_{1)}\right.$} & \multirow{4}{*}{$p_{2}(p 2)$} & \multirow{4}{*}{$p^{2}\left(p^{3}\right)$} \\
\hline & \multicolumn{4}{|c|}{ Pre-operative } & \multicolumn{4}{|c|}{ After one month } & \multicolumn{4}{|c|}{ After three month } & \multicolumn{4}{|c|}{ Pre-operative } & \multicolumn{4}{|c|}{ After one month } & \multicolumn{4}{|c|}{ After three month } & & & \\
\hline & \multicolumn{2}{|c|}{ Unsatisactory } & \multicolumn{2}{|c|}{ Satisfactory } & \multicolumn{2}{|c|}{ Unsatisfactory } & \multicolumn{2}{|c|}{ Satisfactory } & \multicolumn{2}{|c|}{ Unsatisfactory } & \multicolumn{2}{|c|}{ Satisfactory } & \multicolumn{2}{|c|}{ Unsatisfactory Sic $_{\text {in }}$} & \multicolumn{2}{|c|}{ Satisfactory } & \multicolumn{2}{|c|}{ Unsatisactory } & \multicolumn{2}{|c|}{ Satisfactory } & \multicolumn{2}{|c|}{$\begin{array}{lll}\text { Unsatisfactory } & \text { s }\end{array}$} & \multicolumn{2}{|c|}{ Satisfactory } & & & \\
\hline & No. & $\%$ & No. & $\%$ & No. & $\%$ & No. & $\%$ & No. & $\%$ & No. & $\%$ & No. & $\%$ & No. & $\%$ & No. & $\%$ & No. & $\%$ & No. & $\%$ & No. & $\%$ & & & \\
\hline $\begin{array}{l}\text { Knowledge } \\
\text { related to brain } \\
\text { anatomy and } \\
\text { surgery }\end{array}$ & 12 & 100.0 & 0 & 0.0 & 5 & |41.7 | & 75 & 58.33 & 3 & 25.0 & 9 & 75.0 & 12 & $\mid 100.0$ & 0 & 0.0 & 11 & 91.7 & 1 & 8.3 & 11 & 91.7 & 1 & 8.3 & - & $\begin{array}{c}10.971 \\
\left(F^{*} p_{p}\right. \\
0.001)\end{array}$ & 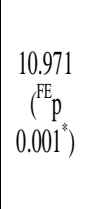 \\
\hline $\begin{array}{l}\text { Knowledge } \\
\text { related to } \\
\text { postoperative } \\
\text { precautions }\end{array}$ & 11 & 91.7 & 1 & 8.3 & 2 & 16.7 & 10 & 83.3 & 2 & 16.7 & 10 & 83.3 & 10 & 83.3 & 2 & 16.7 & 10 & 83.3 & 2 & 16.7 & 10 & 83.3 & 2 & 16.7 & 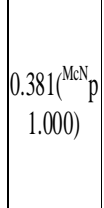 & $\mid \begin{array}{c}10.667^{\circ} \\
\left(\mathrm{F}_{\mathrm{p}}\right. \\
\left.0.001^{\prime}\right)\end{array}$ & $\begin{array}{l}10.667^{*} \\
\mathrm{FE}_{p} \\
\left(0.001^{*}\right)\end{array}$ \\
\hline $\begin{array}{l}\text { Knowledge } \\
\text { related to } \\
\text { infection control } \\
\text { measures }\end{array}$ & 7 & 58.3 & 5 & 41.7 & 2 & 16.7 & 10 & 83.3 & 2 & 16.7 & 10 & 83.3 & 10 & 83.3 & 2 & 16.7 & 8 & 66.7 & 4 & 33.3 & 8 & 66.7 & 4 & 33.3 & $\begin{array}{l}1.815^{(k-1 \times v)} \\
0.371)\end{array}$ & 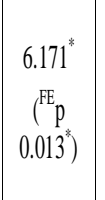 & $\left.\begin{array}{c}6.171^{3} \\
\left({ }^{\mathrm{F}} \mathrm{p}\right. \\
0.013^{3}\end{array}\right)$ \\
\hline $\begin{array}{l}\text { Knowledge } \\
\text { related to } \\
\text { warning signs }\end{array}$ & 12 & 100.0 & 0 & 0.0 & 1 & 8.3 & 11 & 91.7 & 1 & 8.3 & 11 & 91.7 & 12 & $\mid 100.0$ & 0 & 0.0 & 12 & 100.0 & 0 & 0.0 & 12 & 100.0 & 0 & 0.0 & - & 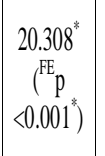 & 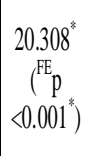 \\
\hline $\begin{array}{l}\text { Knowledge } \\
\text { related to } \\
\text { dealing with } \\
\text { seizures }\end{array}$ & 11 & 91.7 & 1 & 8.3 & 4 & 33.3 & 8 & 66.7 & 4 & 33.3 & 8 & 66.7 & 11 & 91.7 & 1 & 8.3 & 11 & 91.7 & 1 & 8.3 & 11 & 91.7 & 1 & 8.3 & $\begin{array}{l}0.0000^{\text {stev }} \\
1.000)^{p}\end{array}$ & 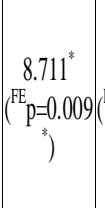 & $\begin{array}{c}8.711^{*} \\
\left({ }^{\mathrm{P}}=0.009\right. \\
1\end{array}$ \\
\hline $\begin{array}{l}\text { Overall } \\
\text { knowledge }\end{array}$ & 11 & 91.7 & 1 & 8.3 & 0 & 0.0 & 12 & 100.0 & 0 & 0.0 & 12 & 100.0 & 12 & 100.0 & 0 & 0.0 & 10 & 83.3 & 2 & 16.7 & 10 & 83.3 & 2 & 16.7 & $\begin{array}{c}1.043 \mathbb{F}_{\mathrm{p}} \\
1.000)\end{array}$ & 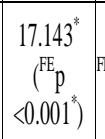 & $\begin{array}{c}17.143^{*} \\
\mathrm{E}_{\mathrm{p}}<0.001 \\
\end{array}$ \\
\hline
\end{tabular}

$\chi^{2}$ : Chi square test FE: Fisher ExactMcN: McNemar test

$p_{1}:$ p value for comparing between the studied groups in before application of the program

$p_{2}:$ v value for comparing between the studied groups in affer application of the program

*: Statistically significant at $p \leq 0.05$ 
Educational Program, Brain Surgeries, Post Operative Outcomes

Table (7): Comparisons between the two study nurses groups in relation to nurses' performance of patients undergoing brain surgeries,preoperatively, one day after discharge from ICU and on discharge day

\begin{tabular}{|c|c|c|c|c|c|c|c|c|c|c|c|c|c|c|c|c|c|c|c|c|c|c|}
\hline \multirow{3}{*}{$\begin{array}{l}\text { Nurses performances } \\
\text { of patients } \\
\text { undergoing brain } \\
\text { surgery }\end{array}$} & \multicolumn{10}{|c|}{ Nurses caring for the study subjects $(\mathrm{n}=12)$} & \multicolumn{9}{|c|}{ Nurses caring for the control subjects $(\mathrm{n}=12)$} & \multirow{3}{*}{$x^{2}\left(p_{1}\right)$} & \multirow{3}{*}{$\chi^{2}\left(p_{2}\right)$} & \multirow{3}{*}{$2^{2}\left(p_{3}\right)$} \\
\hline & & \multicolumn{3}{|c|}{$1^{\text {st }}$ observation } & \multicolumn{3}{|c|}{$2^{\text {nd }}$ observation } & \multicolumn{3}{|c|}{$3^{\text {rd }}$ observation } & \multicolumn{3}{|c|}{$1^{\text {st }}$ observation } & \multicolumn{3}{|c|}{$2^{\text {nd }}$ observation } & \multicolumn{3}{|c|}{$3^{\text {rd }}$ observation } & & & \\
\hline & & Poor & Fair & Good & Poor & Fair & Good & Poor & Fair & Good & Poor & Fair & Good & d Poor & Fair & Good & Poor & Fair & & & & \\
\hline & $\%$ & $\begin{array}{c}12 \\
100 \\
\end{array}$ & 0 & $\begin{array}{c}0 \\
0.0\end{array}$ & 41.7 & & $\begin{array}{c}3 \\
25.0\end{array}$ & $\begin{array}{c}4 \\
33.3\end{array}$ & 25.0 & $\begin{array}{c}5 \\
41.7\end{array}$ & $\begin{array}{l}12 \\
100\end{array}$ & $\begin{array}{c}0 \\
0.0\end{array}$ & 0.0 & $\begin{array}{c}12 \\
100.0\end{array}$ & 0.0 & $\begin{array}{c}0 \\
0.0\end{array}$ & $\begin{array}{c}12 \\
100.0\end{array}$ & 0 & 0.0 & & $\begin{array}{c}9.117^{*} \\
\left(\mathrm{~F}_{\mathrm{F}}^{\mathrm{F}}=0.005^{\circ}\right)\end{array}$ & \\
\hline & $\begin{array}{l}\mathrm{N} 0 . \\
\%\end{array}$ & \begin{tabular}{|c|}
8 \\
66.7 \\
\end{tabular} & $\begin{array}{c}3 \\
25.0\end{array}$ & $\begin{array}{c}1 \\
8.3\end{array}$ & 25.0 & 25.0 & $\begin{array}{c}6 \\
50.0\end{array}$ & $\begin{array}{c}1 \\
8.3\end{array}$ & $\begin{array}{c}3 \\
25.0\end{array}$ & $\begin{array}{c}8 \\
66.7\end{array}$ & $\begin{array}{c}11 \\
91.7\end{array}$ & $\begin{array}{c}1 \\
8.3\end{array}$ & \begin{tabular}{|c|}
0 \\
0.0
\end{tabular} & $\begin{array}{c}9 \\
75.0\end{array}$ & \begin{tabular}{|c|}
2 \\
16.7 \\
\end{tabular} & $\begin{array}{c}1 \\
8.3\end{array}$ & $\begin{array}{c}9 \\
75.0\end{array}$ & \begin{tabular}{|c|}
2 \\
16.7 \\
\end{tabular} & $\begin{array}{c}1 \\
8.3\end{array}$ & $\begin{array}{l}2.326 \\
\mathrm{FE}\end{array}$ & & $12.181^{*}$ \\
\hline ovidi & No. & & - & $\begin{array}{l}- \\
-\end{array}$ & 33.3 & 16.7 & 50.0 & 8.3 & 16.7 & 75.0 & - & - & - & \begin{tabular}{c|}
10 \\
83.3 \\
\end{tabular} & $\begin{array}{c}1 \\
8.3\end{array}$ & $\begin{array}{c}1 \\
8.3\end{array}$ & \begin{tabular}{|c|}
8 \\
66.7
\end{tabular} & $\begin{array}{c}3 \\
25.0\end{array}$ & 8. & & $\left(\begin{array}{c}6.305 \\
\left({ }^{M C}=0.052\right)\end{array}\right.$ & $12.181^{*}$ \\
\hline $\begin{array}{l}\text { Care of } \\
\text { incision }\end{array}$ & $\begin{array}{l}\text { No. } \\
\%\end{array}$ & - & - & $\begin{array}{l}- \\
-\end{array}$ & 8.3 & 25.0 & $\begin{array}{c}8 \\
66.7\end{array}$ & $\begin{array}{c}0 \\
0.0\end{array}$ & 8.3 & $\begin{array}{c}11 \\
91.7\end{array}$ & - & $\begin{array}{l}- \\
-\end{array}$ & - & $\begin{array}{c}9 \\
75.0\end{array}$ & \begin{tabular}{|c|}
3 \\
25.0 \\
\end{tabular} & \begin{tabular}{|c}
0 \\
0.0
\end{tabular} & $\begin{array}{c}7 \\
58.3\end{array}$ & & 16.7 & & $\begin{array}{c}15.125^{*} \\
\left.\left({ }^{M C}<0.001\right)^{*}\right)\end{array}$ & $\left\{\begin{array}{c}14.512^{*} \\
\left({ }^{M C} \mathrm{p}<0.001\right.\end{array}\right.$ \\
\hline & No. & & - & - & $\begin{array}{c}0 \\
0.0\end{array}$ & & $\begin{array}{c}10 \\
83.3\end{array}$ & $\begin{array}{c}0 \\
0.0\end{array}$ & $\begin{array}{c}1 \\
8.3\end{array}$ & $\begin{array}{c}11 \\
91.7\end{array}$ & - & - & $\begin{array}{l}- \\
-\end{array}$ & \begin{tabular}{|c|}
9 \\
75.0
\end{tabular} & $\begin{array}{c}2 \\
16.7\end{array}$ & \begin{tabular}{|c|}
1 \\
8.3
\end{tabular} & $\begin{array}{c}7 \\
58.3\end{array}$ & \begin{tabular}{|c|}
4 \\
33.3
\end{tabular} & 8.3 & & 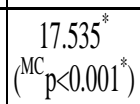 & $\begin{array}{c}17.667^{*} \\
\left({ }^{M C} p<0.001\right.\end{array}$ \\
\hline plyin & $\begin{array}{l}\mathrm{N} 0 . \\
\%\end{array}$ & & $\begin{array}{c}1 \\
8.3\end{array}$ & $\begin{array}{c}6 \\
50.0\end{array}$ & 16.7 & 16.7 & $\begin{array}{c}8 \\
66.7\end{array}$ & $\begin{array}{c}0 \\
0.0\end{array}$ & $\begin{array}{c}2 \\
16.7\end{array}$ & 10 & $\begin{array}{c}8 \\
66.7\end{array}$ & $\begin{array}{c}0 \\
0.0\end{array}$ & 33.3 & $\begin{array}{c}7 \\
58.3\end{array}$ & $\begin{array}{c}1 \\
8.3 \\
\end{array}$ & $\begin{array}{c}4 \\
33.3\end{array}$ & $\begin{array}{c}6 \\
50.0\end{array}$ & \begin{tabular}{|c|}
1 \\
8.3
\end{tabular} & \begin{tabular}{|c|}
5 \\
41.7 \\
\end{tabular} & $\begin{array}{c}2.014 \\
\left.M \mathrm{C}_{\mathrm{p}}=0.422\right)\end{array}$ & & $\begin{array}{c}8.085^{*} \\
\mathrm{MC} p=0.019\end{array}$ \\
\hline " & $\begin{array}{l}\mathrm{N} 0 . \\
\%\end{array}$ & \begin{tabular}{|c|}
3 \\
25.0
\end{tabular} & \begin{tabular}{|c|}
3 \\
25.0
\end{tabular} & $\begin{array}{c}6 \\
50.0\end{array}$ & $\begin{array}{c}3 \\
25.0\end{array}$ & 16.7 & $\begin{array}{c}7 \\
58.3\end{array}$ & $\begin{array}{c}1 \\
8.3\end{array}$ & $\begin{array}{c}2 \\
16.7\end{array}$ & $\begin{array}{c}9 \\
75.0\end{array}$ & \begin{tabular}{|c|}
11 \\
91.7
\end{tabular} & \begin{tabular}{|c}
1 \\
8.3
\end{tabular} & \begin{tabular}{|c|}
0 \\
0.0
\end{tabular} & \begin{tabular}{|c|}
10 \\
83.3
\end{tabular} & \begin{tabular}{|c|}
1 \\
8.3 \\
\end{tabular} & \begin{tabular}{|c|}
1 \\
8.3
\end{tabular} & $\begin{array}{c}10 \\
83.3\end{array}$ & $\begin{array}{c}1 \\
8.3\end{array}$ & \begin{tabular}{|c|}
1 \\
8.3 \\
\end{tabular} & 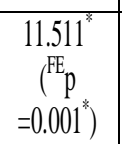 & $\begin{array}{c}8.484^{*} \\
\left(\mathrm{FE}_{\mathrm{p}} \mathrm{p}=0.0066^{\circ}\right)\end{array}$ & $\begin{array}{r}14.499^{*} \\
\left(\mathrm{~F}_{\mathrm{p}} \mathrm{p}=0.001\right.\end{array}$ \\
\hline 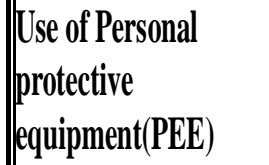 & No. & \begin{tabular}{|c|}
12 \\
100.0
\end{tabular} & $\begin{array}{c}0 \\
0.0\end{array}$ & \begin{tabular}{|c|}
0 \\
0.0
\end{tabular} & 33.3 & 16.7 & $\begin{array}{c}6 \\
50.0\end{array}$ & $\begin{array}{c}1 \\
8.3\end{array}$ & 25.0 & $\begin{array}{c}8 \\
66.7\end{array}$ & $\begin{array}{c}12 \\
100.0\end{array}$ & 0 & $\begin{array}{c}0 \\
0.0\end{array}$ & $\begin{array}{c}11 \\
91.7\end{array}$ & 8.3 & $\begin{array}{c}0 \\
0.0\end{array}$ & $\begin{array}{c}10 \\
83.3\end{array}$ & $\begin{array}{c}1 \\
8.3\end{array}$ & & 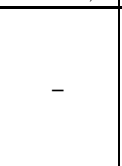 & $\begin{array}{l}9.662^{*} \\
M{ }^{M} \\
\left.p=0.003^{*}\right)\end{array}$ & $\begin{array}{c}13.951^{*} \\
{ }^{M C}{ }^{*}=0.001\end{array}$ \\
\hline Dispose of waste & $\begin{array}{l}\text { No. } \\
\% \\
\end{array}$ & \begin{tabular}{|c|}
0 \\
0.0 \\
\end{tabular} & & \begin{tabular}{|c|}
12 \\
100 \\
\end{tabular} & 0.0 & & $\begin{array}{l}12 \\
100 \\
\end{array}$ & 0.0 & $\begin{array}{c}0 \\
0.0 \\
\end{array}$ & $\begin{array}{c}12 \\
100 \\
\end{array}$ & $\begin{array}{c}0 \\
0.0 \\
\end{array}$ & $\begin{array}{c}0 \\
0.0 \\
\end{array}$ & $\begin{array}{l}12 \\
100 \\
\end{array}$ & 0.0 & $\begin{array}{c}0 \\
0.0 \\
\end{array}$ & $\begin{array}{c}12 \\
100 \\
\end{array}$ & $\begin{array}{c}0 \\
0.0 \\
\end{array}$ & $\begin{array}{c}0 \\
0.0\end{array}$ & & & - & \\
\hline & $\begin{array}{l}\mathrm{N} 0 . \\
\% \\
\end{array}$ & \begin{tabular}{|c|}
11 \\
91.7 \\
\end{tabular} & $\begin{array}{c}1 \\
8.3 \\
\end{array}$ & $\begin{array}{c}0 \\
0.0 \\
\end{array}$ & $\begin{array}{c}1 \\
8.3 \\
\end{array}$ & 25.0 & $\begin{array}{c}8 \\
66.7\end{array}$ & $\begin{array}{c}1 \\
8.3 \\
\end{array}$ & $\begin{array}{c}2 \\
16.7\end{array}$ & $\begin{array}{c}9 \\
75.0\end{array}$ & $\begin{array}{c}12 \\
100 \\
\end{array}$ & $\begin{array}{c}0 \\
0.0\end{array}$ & $\begin{array}{c}0 \\
0.0\end{array}$ & $\begin{array}{c}11 \\
91.7 \\
\end{array}$ & \begin{tabular}{|c|}
1 \\
8.3 \\
\end{tabular} & $\begin{array}{c}0 \\
0.0\end{array}$ & $\begin{array}{c}11 \\
91.7\end{array}$ & $\begin{array}{c}1 \\
8.3 \\
\end{array}$ & $\begin{array}{c}0 \\
0.0 \\
\end{array}$ & $\begin{array}{c}1.043 \\
\left(\mathrm{~F} \mathrm{~F}_{\mathrm{p}}=1.000\right)\end{array}$ & 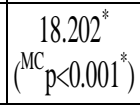 & $\begin{array}{c}18.948^{*} \\
\left({ }^{M C} p<0.001\right.\end{array}$ \\
\hline ent & No. & \begin{tabular}{|c|}
10 \\
83.3 \\
\end{tabular} & $\begin{array}{c}1 \\
8.3\end{array}$ & $\begin{array}{c}1 \\
8.3\end{array}$ & $\begin{array}{c}1 \\
8.3\end{array}$ & $\begin{array}{c}2 \\
16.7\end{array}$ & $\begin{array}{c}9 \\
75.0\end{array}$ & $\begin{array}{c}0 \\
0.0\end{array}$ & $\begin{array}{c}2 \\
16.7\end{array}$ & $\begin{array}{c}10 \\
83.3\end{array}$ & $\begin{array}{c}10 \\
83.3\end{array}$ & $\begin{array}{c}2 \\
16.7\end{array}$ & $\begin{array}{c}0 \\
0.0\end{array}$ & $\begin{array}{c}10 \\
83.3\end{array}$ & \begin{tabular}{|c|}
2 \\
16.7 \\
\end{tabular} & \begin{tabular}{|c|}
0 \\
0.0
\end{tabular} & $\begin{array}{c}10 \\
83.3\end{array}$ & $\begin{array}{c}1 \\
8.3\end{array}$ & 1 & $\begin{array}{c}1.350 \\
\left.M C_{p}=1.000\right)\end{array}$ & $\begin{array}{c}17.53{ }^{*} \\
\left.\left.{ }^{M C}<<0.001\right)^{*}\right)\end{array}$ & $\begin{array}{c}19.10^{*} \\
\left.{ }^{M C} \mathrm{c} p 0.001^{*}\right)\end{array}$ \\
\hline trail & & 8 & & $\begin{array}{c}3 \\
25.0\end{array}$ & & & $\begin{array}{c}8 \\
66.7\end{array}$ & $\begin{array}{c}1 \\
8.3\end{array}$ & 10.1 & & \begin{tabular}{|c|}
10 \\
83.3
\end{tabular} & $\begin{array}{c}1 \\
8.3\end{array}$ & & $\left|\begin{array}{c}9 \\
75.0\end{array}\right|$ & & \begin{tabular}{|c}
2 \\
16.7
\end{tabular} & 8 & $\begin{array}{c}2 \\
16.7\end{array}$ & & 1.394 & $\begin{array}{c}8.271^{*} \\
\left.M M^{2}=0.015^{5}\right)\end{array}$ & $\left(\mathrm{NC}_{\mathrm{p}=0.00}\right.$ \\
\hline
\end{tabular}

$\chi^{2}$ : Chi square test FE: Fisher ExactMc: Montcarlo test

$p_{2}: p$ value for comparing between the studied groups in after application of the program $p_{1}: p$ value for comparing between the studied groups in before application of the program

$*$ Statistically significant at $p \leq 0.05$ 


\section{References}

1. Guilabert PMH, Herrera I, Taranilla F. The postoperative cranium, normal findings and complications. European Congress of Radiology 2013:1-25.

2. Hadanny A, Rozovski U, Nossek E, Shapira Y, Strauss I, Kanner AA, et al. Craniectomy Versus Craniotomy for Posterior Fossa Metastases: Complication Profile. World Neurosurg 2016; 89:193-8.

3. Haddad S, Spir A, Craft S, Hart.S. Benefits of patient education, Patient Education Institute. Available at: http://ww2.patienteducation.com/main.asp?p=aboutus\&s=bope\&f s=aboutus\&mode=FULL. [Retrieved on: Jan, 2019]. 2013.

4. Yarbro C, Wujcik D, Gobel B. Therapeutic Approaches and Nursing care Surgery. In: Yarbro C, Wujcik D, Gobel B (eds). Cancer Nursing: Principles and practice, Central nervous system cancers. $7^{\text {th }}$ ed. London: Jones and Barlett Publisher; 2011. 1167-78.

5. Martha E. Nursing Interventions \& Clinical Skills. $4^{\text {th }}$ ed. Philadelphia: Lippincott Williams \& Wilkins; 2008. 43-76.

6. McGlinsey A, Kirk A. Neurological assessment, Early identification of neurological deterioration is vital to preventing secondary brain injury. 2014.

7. Chunlaka P. International patients' satisfaction towards nurses' service quality at samitivejsrinakarin hospital. Master of Arts Degree in Business English, International Communication, Srinakharinwirot University. 2011.

8. Bin-Madhi K. Brain tumors excision guided by neuronavigation: Practical application and results. Faculty of Medicine: Assiut University 2012.

9. Dankner M. Clinical handbook of psychological disorders. $2^{\text {nd }}$ ed. New York: Guildford; 2009. 180-234.

10. Amit M. Craniotomy series Indication. U.S. National Library of Medicine. Available at: https://medlineplus.gov/ency/presentations. [Retrieved on: Jan, 2019]. 2019.

11. White L, Duncan G, Baumle W. Medical Surgical Nursing: An intended approach, Caring forlients with brain disordersb. $3^{\text {rd }} \mathrm{ed}$. Delmar: Cengage Learning; 2013. 8.

12. Van de Beek D, Drake JM, Tunkel AR. Nosocomial bacterial meningitis. N Engl J Med 2010; 362(2):146-54.

13. Mandelzweig L, Novikov I, Sadetzki S. Smoking and risk of glioma: a meta-analysis. Cancer Causes Control 2009; 20(10):1927-38.
14. Krucik G. Brain tumor. Available at: http://www.healthline.com/health/braintumor. [Retrieved on: Jan, 2018]. 2012.

15. Urden L, Stacy K, Lough M. Critical Care Nursing. $6^{\text {th }}$ ed. USA: Mosby, Elsevier Inc; 2010. 945-9.

16. Amirjamshidi A, Abouzari M, Rashidi A. Glasgow Coma Scale on admission is correlated with postoperative Glasgow Outcome Scale in chronic subdural hematoma. Journal of clinical neuroscience 2007; 14(12):1240-1.

17. Buttaro A. The relationship between socail support and quality of life in patients with brain disorder. Journal of Pakistan Medical Association 2013; 63(4):463-7.

18. Lindsay W, Bone I, Callander R. Neurology and neurosurgery illustrated. Philadelphia: Churchill Livingstone; 2004. 299,351.

19. Westcarth L, Armstrong T. Diagnostic reasoning seizures in people with cancer. Clinical Journal of Oncology Nursing 2007; 11(8):265-87.

20. Spears P. The impact of the nursing beducational sessions for nurses on post surgery outcomes. J Nurs Adm 2005; 35(5):223-4.

21. Elrefaay N. Assessment of nurses' practices related to safety of intraoperative surgical patients undergoing general anesthesia: Faculty of Nursing: Alexandria University; 2012.

22. Annette D, Gilmour JA. Medical- Surgical Nursing: Assessment and Management of Clinical Problems. $2^{\text {nd }}$ ed. Australia: Brown and Edwards Company; 2007. 189.

23. Aiken LH, Sermeus W, Van den Heede K, Sloane DM, Busse R, McKee M, et al. Patient safety, satisfaction, and quality of hospital care: cross sectional surveys of nurses and patients in 12 countries in Europe and the United States. British Medical Journal 2012; 344:e1717.

24. Shrestha R. Impact of educational interventions on nurses' knowledge regarding care of patient with central venous line. Journal of Kathmandu Medical College 2013; 2(1):28-30.

25. Ookalkar A, Joshi AG, Ookalkar DS. Quality improvement in haemodialysis process using FMEA. International Journal of Quality \& Reliability Management 2009; 26(8):817-30. 